\title{
Standardization of Eco-Friendly Retail Packages for Freshness Retention and Shelf Life Extension of Jasmine Flower
}

\author{
S. Bhuvaneswari" and Sangama \\ ICAR-Indian Institute of Horticultural Research, Hesaraghatta lake (PO) \\ Bengaluru-560089, India \\ *Corresponding author
}

\section{A B S T R A C T}

Jasmine is one among the important commercial flower crops popular for its pleasent fragrance in domestic as well as export market. Packaging material plays an important role in retention of freshness of jasmine flowers. At present jasmine flowers are packed in bulk in wet gunny bags and sold in whole sale market. For retail market, jasmine flowers are

Keywords

Jasmine flower, Retail pack, Areca nut sheath cup, Peepil leaf cup, Banana sheath cup

Article Info

Accepted: 08 January 2018 Available Online: 10 February 2018 loosely packed in polyethylene cover of jasmine flowers which is not eco-friendly. Hence an attempt is made to standardise alternate eco-friendly packages for retail market which will retain freshness and extend the shelf life of jasmine flowers. Experiments were conducted by packaging loose jasmine flowers in arecanut sheath cup, banana sheath cup and peepil leaf cup. The samples were stored in both ambient (Temp $25-26^{\circ} \mathrm{C}, \mathrm{RH} 52 \%$ ) and low temperature (Temp $10^{\circ} \mathrm{C}, \mathrm{RH} 86 \%$ ). Periodical observations on colour index, freshness index and fragrance index were done using standard procedures. It was found from the studies that areca nut sheath cup was found suitable for retail packaging of jasmine with higher freshness $(82.26 \%)$, colour $(78.15 \%)$ and fragrance $(71.21 \%)$ indices. The samples had shelf life up to 2 days in ambient storage condition when compared to those packed in banana sheath cup and peepil cup which had less freshness and fragrance index in similar storage condition. In low temperature storage also jasmine flower packed in areca nut sheath cup had freshness index (81.94\%), colour index $(59.98 \%)$ and fragrance index (58.52\%) and less spoilage (7.08\%), as compared to those packed in banana sheath cup and peepil leaf cup. The shelf life of the sample was 7 days in low temperature storage. This technology of retail packing of jasmine flower in areca nut sheath cup could be widely adopted in super market and e- marketing.

\section{Introduction}

Jasmine is one among the important commercial flower crops popular for its pleasent fragrance in domestic as well as export market. Packaging material plays an important role in retention of freshness of jasmine flowers. At present jasmine flowers are packed in bulk in wet gunny bags and sold in whole sale market. Jasmine loose flowers are packed in bamboo basket (around 10-15kg are packed in each basket) and the baskets covered with wet gunny bags or muslin cloth (Safeena et al., 2015). They are transported to the nearby wholesale market for selling. For retail market, polyethylene covers are largely 
used for packaging of jasmine flowers which is not eco-friendly. Roy Chowdhury et al., 2011) observed the beneficial effect of banana sheath over polyethylene and polypropylene in the packaging experiment of jasmine. An attempt is made to standardise eco-friendly packages like areca nut sheath cup, banana sheath cup and peepil leaf cup which will retain freshness and extend the shelf life of jasmine flowers.

\section{Materials and Methods}

Experiments were conducted by packaging loose jasmine flowers in areca nut sheath cup, banana sheath cup and peepil leaf cup. The samples were stored in both ambient (Temp $25-26^{\circ} \mathrm{C}, \mathrm{RH} 52 \%$ ) and low temperature (Temp $10^{\circ} \mathrm{C}, \mathrm{RH} 83 \%$ ).

Periodical observations on PLW, colour index, freshness index and fragrance index were done. The PLW was computed by subtracting fresh weight of flowers on any day from its weight on the previous day and expressed as percentage.

Visual observations such as colour retention Index, freshness index, fragrance index and shelf life (days) were recorded as sensory evaluation scoring based on Madhu (1999).

All the experiments were conducted with four replications and statistically analyzed using Completely Randomised Design (CRD) with WASP 2.0 software (Bhuvaneswari et al., 2015)

\section{Results and Discussion}

\section{Freshness index}

Among different packages studied, freshness index $(\%)$ of jasmine flower was higher in areca nut sheath cup (82.26), followed by banana sheath cup (78.38), peepil leaf cup
(77.14) at ambient storage condition (Table 1). In low temperature storage, freshness index in the areca nut sheath cup is lesser than banana sheath cup and peepil leaf cup (Table 2). Packaging maintains higher humidity which slows down the process of moisture loss. Respiration loss also slows down due to proper balance of $\mathrm{Co}_{2}$ and $\mathrm{O}_{2}$ (Anzueto and Rizve, 1985).

\section{Fragrance index}

Similarly fragrance index which is the important quality character was higher in jasmine packed in areca nut sheath cup (71.21\%), followed by banana sheath cup and peepil leaf cup (66.67\%) both in ambient and low temperature storage (Table 1 and 2). This may be due to biological nature of areca nut sheath to retain the fragrance without any off flavour development.

These results are in accordance with the findings of Karuppaiah et al., (2006). The fragrance retention of jasmine was higher in areca nut sheath cup kept in low temperature storage $(73.33 \%)$ even after seven days of storage than in ambient condition.

\section{Colour index}

Colour index which is used to determine the retention of whiteness of jasmine flower during storage was also higher in the flowers packed in areca sheath cup both in ambient and low temperature storage when compared to other package. Low temperature storage of jasmine in areca sheath cup had good colour retention upto 7 days of storage as compared to those stored at ambient condition for 2 days (Fig. 2). These results are in agreement with extension of shelf life of jasmine flowers for 5 days in low temperature storage by Thamarai selvi et al., (2010). Higher relative humidity and lower temperature might have favoured the colour retention of jasmine flower. 


\section{Experiment details}

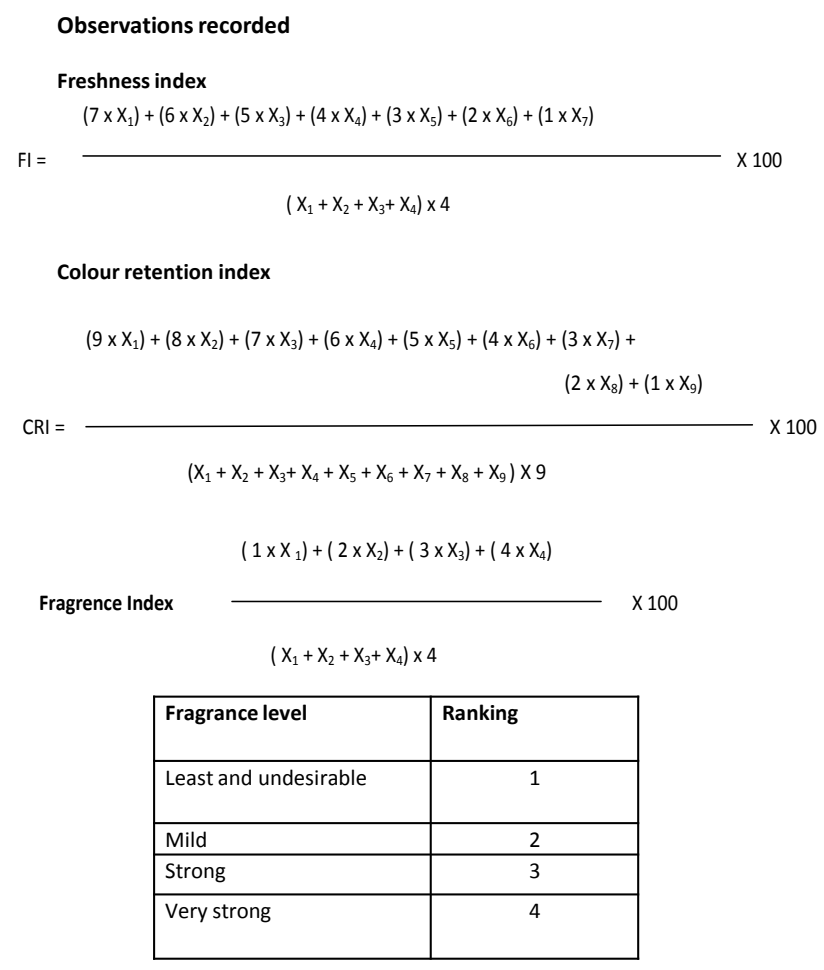

\begin{tabular}{|l|c|c|}
\hline \multicolumn{1}{|c|}{ Condition of flowers } & Score & $\begin{array}{c}\text { Number of } \\
\text { flower buds }\end{array}$ \\
\hline Almost all buds & 7 & $\mathrm{X}_{1}$ \\
\hline Partial to half open flowers & 6 & $\mathrm{X}_{2}$ \\
\hline Half to full open flowers & 5 & $\mathrm{X}_{3}$ \\
\hline $\begin{array}{l}\text { Partial to half open flowers, } \\
\text { slightly wilted }\end{array}$ & 4 & $\mathrm{X}_{4}$ \\
\hline $\begin{array}{l}\text { Half to full open flowers, } \\
\text { slightly wilted }\end{array}$ & 3 & $\mathrm{X}_{5}$ \\
\hline $\begin{array}{l}\text { Partial to half open flowers, } \\
\text { fully wilted }\end{array}$ & 2 & $\mathrm{X}_{6}$ \\
\hline $\begin{array}{l}\text { Half to full open flowers } \\
\text { fully wilted }\end{array}$ & 1 & $\mathrm{X}_{7}$ \\
\hline
\end{tabular}

\begin{tabular}{|l|c|c|}
\hline \multicolumn{1}{|c|}{ Flower colour } & Score & $\begin{array}{c}\text { Number of flower } \\
\text { buds }\end{array}$ \\
\hline Bright white & 9 & $\mathrm{X}_{1}$ \\
\hline Dull white & 8 & $\mathrm{X}_{2}$ \\
\hline Cream or yellowish & 7 & $\mathrm{X}_{3}$ \\
\hline 1 to $10 \%$ brown & 6 & $\mathrm{X}_{4}$ \\
\hline 11 to $15 \%$ brown & 5 & $\mathrm{X}_{5}$ \\
\hline 16 to $50 \%$ brown & 4 & $\mathrm{X}_{6}$ \\
\hline 51 to $75 \%$ brown & 3 & $\mathrm{X}_{7}$ \\
\hline 76 to $90 \%$ brown & 2 & $\mathrm{X}_{8}$ \\
\hline All brown & 1 & $\mathrm{X}_{9}$ \\
\hline
\end{tabular}

Table.1 Jasmine in retail packages at ambient storage (Temp. $25-26^{\circ} \mathrm{C}$, RH $52 \%$ ) after $48 \mathrm{~h}$ of storage

\begin{tabular}{|l|c|c|c|c|}
\multicolumn{1}{|c|}{ Treatments } & $\begin{array}{c}\text { Freshness } \\
\text { Index }\end{array}$ & $\begin{array}{c}\text { Colour retention } \\
\text { Index }\end{array}$ & $\begin{array}{c}\text { Fragranc } \\
\text { e Index }\end{array}$ & $\begin{array}{c}\text { PLW } \\
(\%)\end{array}$ \\
\hline Peepil Leaf cup & 77.14 & 76.51 & 66.67 & 8.33 \\
\hline Arecanut shealth cup & 82.26 & 78.15 & 71.21 & 10 \\
\hline Banana shealth cup & 78.38 & 77.18 & 66.67 & 8.33 \\
\hline CD (1\%) & 2.38 & 1.42 & 1.36 & 1.52 \\
\hline
\end{tabular}

Table.2 Jasmine in retail packages at low temperature storage (Temp $8^{0} \mathrm{C}, \mathrm{RH} 85 \%$ ) after 7 days of storage

\begin{tabular}{|l|c|c|c|c|c|}
\multicolumn{1}{|c|}{ Treatments } & $\begin{array}{c}\text { Freshness } \\
\text { Index }\end{array}$ & $\begin{array}{c}\text { Colour retention } \\
\text { Index }\end{array}$ & $\begin{array}{c}\text { Fragrance } \\
\text { Index }\end{array}$ & $\begin{array}{c}\text { PLW } \\
(\boldsymbol{\%})\end{array}$ & $\begin{array}{c}\text { Spoilage } \\
(\boldsymbol{\%})\end{array}$ \\
\hline Peepil Leaf cup & 89.94 & 64.83 & 65.33 & 5.97 & 15.89 \\
\hline Arecanut sheath cup & 81.94 & 61.98 & 58.52 & 7.6 & 7.08 \\
\hline Banana sheath cup & 87.88 & 63.15 & 64.65 & 4.16 & 8.37 \\
\hline CD (1\%) & 1.955 & 1.948 & 2.275 & 1.394 & 2.060 \\
\hline
\end{tabular}


Fig.1a, b, c Jasmine flower in different packages at ambient storage (Temp. $25-26^{\circ} \mathrm{C}$, RH 52\%)

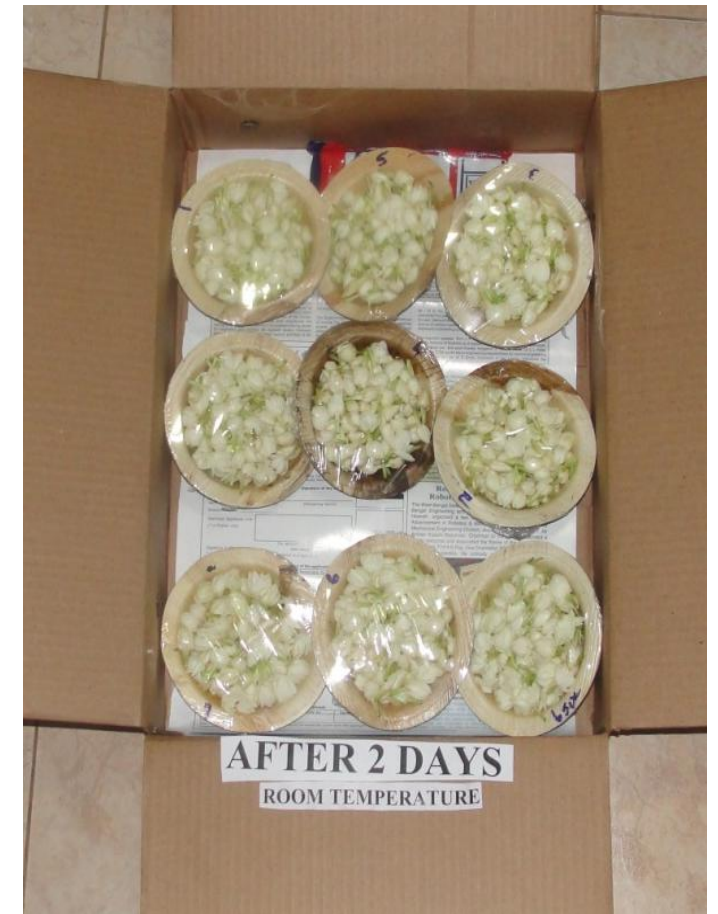

Fig.1a Jasmine flower in areca nut sheath cup

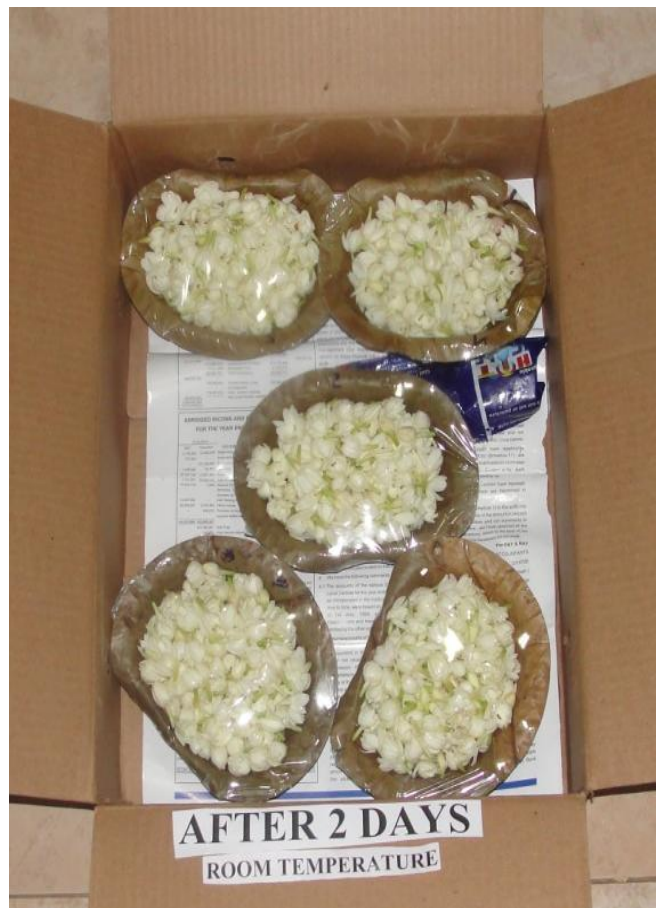

Fig.1b Jasmine flower in peepil leaf cup

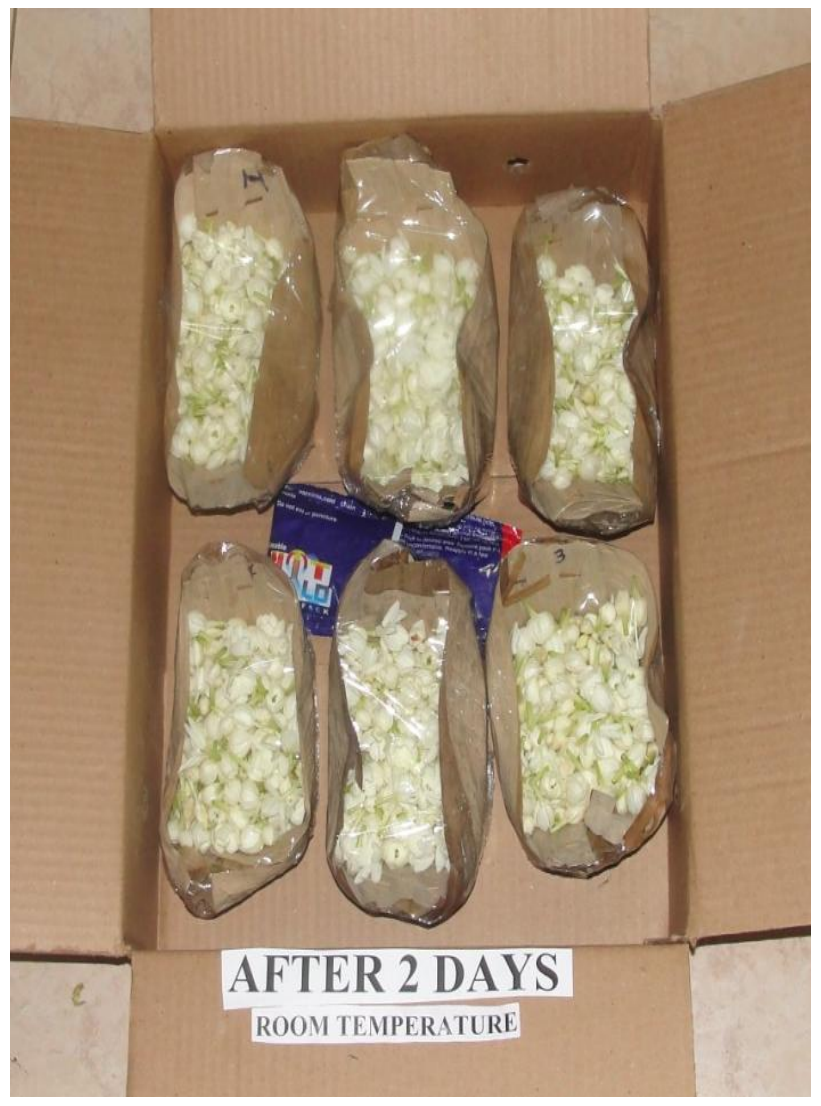

Fig.1c Jasmine flower in banana sheath cup 
Fig.2 Jasmine in different packages at low temperature storage (Temp. $10^{\circ} \mathrm{C}, \mathrm{RH} 83 \%$ )

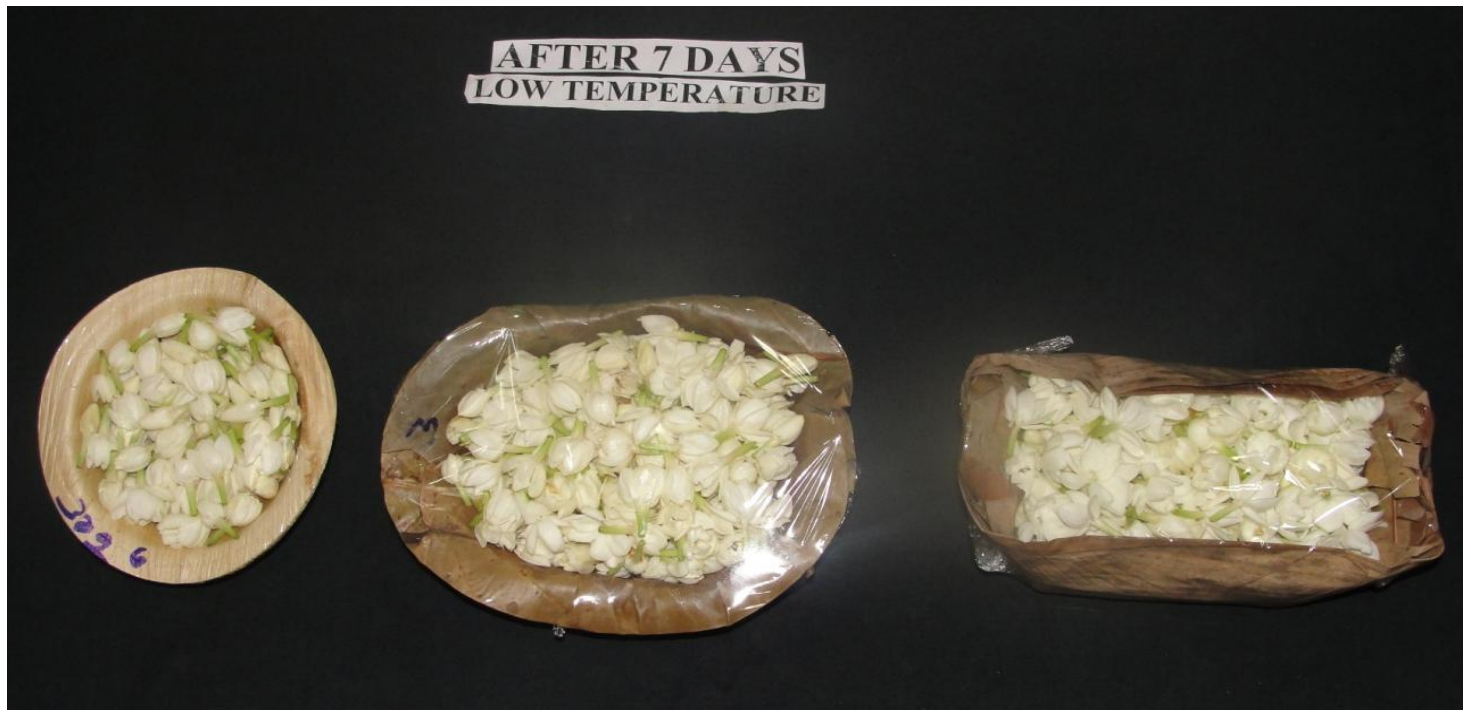

\section{Shelf life}

The spoilage $(\%)$ of jasmine flower in areca nut cup package $(7.08 \%)$ which was lesser by $50 \%$ as compared to peepil leaf packages $(15.89 \%)$ in low temperature storage (Table 2). The shelf life of jasmine flowers in all the retail packages were 7 days in low temperature storage and 2 days in ambient storage condition.

It was found from the studies that areca nut sheath cup was found suitable eco-friendly retail package for jasmine flower with higher freshness and fragrance indices with lesser spoilage both in ambient (Temp. $25-26^{\circ} \mathrm{C}$, RH $52 \%$ ) and low temperature (Temp $8^{\circ} \mathrm{C}, \mathrm{RH}$ $85 \%$ ) storage (Fig. 1). The jasmine flower had shelf life of 2 days in ambient storage condition with areca nut cup as primary pack and corrugated fibre board box (CFB box) with gel pack as secondary pack. The jasmine flower packed in areca nut package had shelf life of 7 days in low temperature storage.

\section{References}

Anzueto GR and Rizve SSH. 1985. Individual packaging of apples for shelf life extension. Journal of Food Science.50 897-900.

Bhuvaneswari S, Narayana C K, Udhayakumar $\mathrm{R}$ and Veeregowda $\mathrm{R}$. 2015. Effect of packaging and storage temperature on shelf life of minimally processed onion (Allium cepa L.). Journal of Horticultural Sciences. 10(2): 216-219.

Karuppaiah P, Ramesh Kumar S and Raj kumar M. 2006. Effect of different packages on the post-harvest behaviour and shelf life of jasmine (Jasminum sambac). Internat. J. Agric. Sci. 2(2): 447-449

Madhu GR. 1999. Studies on the effect of different packaging materials and chemicals on the post-harvest life of Jasmine flowers. M.Sc. (Ag.) thesis submitted to Annamalai University, Annamalainagar, Tamil Nadu

Roy chowdhury N, Chakrabarty $\mathrm{S}$ and $\mathrm{P}$. Munsi P. 2011. Influence of Packaging Material, Storage Condition and Storage Duration on Vase Life of Jasmine 'Calcutta Double'. Proc. Xth IS on Flower Bulbs and Herbaceous Perennials. Acta Hort. 886, ISHS.pp 359-364 
Safeena SA, Thangam M, Priya Devi S, Desai AR and Singh N P. 2015. Ready Reckoner on Cultivation of Jasmine. Technical Bulletin No: 50, ICARCentral Coastal Agricultural Research Institute (Indian Council of Agricultural Research), Ela, Old Goa-403 402, Goa,
India.

Thamaraiselvi S.P, Jawaharlal M, Ganga M and Varadharaju N 2010. Packaging technology for long term storage of Jasmine (Jasminum sambac Ait.) flowers. Journal of Ornamental Horticulture, 13 (3):171-181

\section{How to cite this article:}

Bhuvaneswari, S. and Sangama. 2018. Standardisation of Eco-Friendly Retail Packages for Freshness Retention and Shelf Life Extension of Jasmine Flower. Int.J.Curr.Microbiol.App.Sci. 7(02): 494-499. doi: https://doi.org/10.20546/ijcmas.2018.702.062 